\title{
Pengaruh Kualitas Laporan Keuangan Terhadap Efisiensi Investasi
}

\section{Gede Diatmika Putra I Gst. Ayu Eka Damayanthi}

\author{
${ }^{1,2}$ Fakultas Ekonomi dan Bisnis Universitas Udayana (Unud), Bali, Indonesia \\ e-mail: diatmikap@gmail.com
}

\begin{abstract}
ABSTRAK
Tujuan penelitian ini adalah untuk mengetahui bagaimana pengaruh kualitas laporan keuangan terhadap kondisi underinvestment dan overinvestment. Penelitian dilakukan pada perusahaan pertambangan yang terdaftar di Bursa Efek Indonesia tahun 2017. Jumlah sampel pada penelitian ini adalah 38 perusahaan. Metode pengumpulan data yang digunakan adalah metode non probability sampling dengan teknik purposive sampling. Teknik analisis data yang digunakan adalah analisis statistik deskriptif, uji kelayakan model,analisis regresi multinomial logistik, dan uji statistika Wald. Hasil analisis menemukan bahwa kualitas laporan keuangan berpengaruh negatif pada kondisi underinvestment dan overinvestment. Perusahaan dengan nilai kualitas laporan keuangan yang tinggi akan menyebabkan menurunnya probabilitas perusahaan yang mengalami kondisi underinvestment dibandingkan dengan probabilitas perusahaan dalam kondisi investasi normal. Kualitas laporan keuangan yang baik dapat meningkatkan fungsi monitoring bagi pemegang saham dalam mengawasi keputusan investasi yang dibuat oleh manajer untuk menghindari kondisi overinvestment.
\end{abstract}

Kata kunci: Efisiensi investasi, underinvestment,overinvestment, kualitas laporan keuangan.

\begin{abstract}
The aim of this research is to determine how the quality of financial reports on underinvestment and overinvestment conditions are affected. The research was conducted on mining companies listed in the Indonesian Stock Exchange in 2017. The number of samples on this research is 38 companies. The method of data collection used is non-technical sampling method with purposisive sampling. The analysis of the data analysis used is descriptive statistical analysis, model feasibility, multi-logistics regression analysis, and Walid statistics test. The analysis found that the quality of financial reports is negative in underinvestment and overinvestment conditions. The company's high quality financial report would result in a decrease in company probants that experienced underinvestment conditions compared to the company's probability in normal investment conditions. The quality of good financial reports can improve monitoring function for shareholders in monitoring investment decisions made by managers to avoid overinvestment conditions.

Keywords: Investment efficiency, unverinvestment, overinvestment, the quality of financial report.
\end{abstract}




\section{PENDAHULUAN}

Pasar modal telah memberikan peluang bagi siapa saja untuk melakukan investasi. Pasar modal merupakan wadah bagi para investor untuk menanamkan modalnya agar terus berkembang dan juga merupakan suatu fasilitas untuk mempermudah kegiatan investasi. Investasi merupakan kegiatan dimana perusahaan mengalokasikan dana yang dimilikinya dalam periode tertentu dengan harapan akan memperoleh pengembalian dari sejumlah dana yang telah dialokasikan tersebut (Priyakusuma, 2013).

Efisiensi investasi merupakan tingkat investasi optimal dari perusahaan, dimana investasi tersebut merupakan jenis investasi yang menguntungkan bagi perusahaan. Salah satu kriteria yang dapat digunakan perusahaan untuk membuat keputusan investasinya adalah menggunakan Net Present Value (NPV). Manajer akan menilai NPV dari proyek investasi yang ditawarkan. Ross, Westerfield, \& Jordan (2008) mengatakan bahwa net present value merupakan perbedaan harga sebuah investasi di pasar dibandingkan dengan nilai perolehannya. Apabila sebuah investasi bernilai NPV tinggi, maka investasi tersebut harus diambil atau diterima oleh perusahaan tersebut karena investasi tersebut akan mendatangkan keuntungan yang optimal kedepannya bagi perusahaan. Apabila perusahaan mengambil proyek dengan nilai NPV rendah, maka dapat dikatakan bahwa perusahaan dalam keadaan overinvestment dan sebaliknya, jika perusahaan melawatkan kesempatan untuk mengambil proyek dengan nilai NPV tinggi, maka perusahaan dikatakan dalam keadaan underinvestment (Biddle, Hilary, \& Verdi, 2009) 
Kondisi underinvestment muncul apabila perusahaan menghadapi kesempatan investasi pada proyek dengan NPV tinggi, dimana mensyaratkan penggunaan hutang dengan jumlah yang besar, tanpa jaminan pembayaran utang yang mencukupi (free cash flow). Kondisi tersebut cenderung dialami oleh perusahaan dengan tingkat leverage yang tinggi. Berbeda dengan perusahaan yang mengalami kondisi underinvestment, Perusahaan dengan permasalahan overinvestment pada umumnya adalah perusahaan yang berada pada tahap mature dengan tingkat pertumbuhan yang lambat (slow growth), serta memiliki assets in place dan free cash flow yang tinggi. Jensen (1986) berpendapat bahwa adanya kelebihan modal (free cash flow) pada perusahaan dengan tingkat pertumbuhan lambat menjadi penyebab munculnya masalah overinvestment, yakni perusahaan pada tahap ini memiliki kesempatan investasi yang rendah sehingga perusahaan mengalami keadaan "bingung" ingin berinvetasi kemana lagi sehingga manajer memaksakan kebijakan investasi tetap ada karena dengan sedikitnya investasi maka manajer akan mendapatkan sedikit gaji.

Adanya agency conflict mengakibatkan timbulnya asimetri informasi antara pemegang saham dan manajer perusahaan. Asimetri informasi ini juga merupakan faktor yang mempengaruhi investasi perusahaan. Asimetri informasi merupakan perbedaan informasi yang dimiliki antara agen (pemegang saham) dan prinsipal (manajemen). Manajemen perusahaan merupakan pihak internal perusahaan, sehingga manajemen lebih mengetahui segala informasi yang terkait dengan perusahaan dan prospek dari perusahaan itu sendiri. Sedangkan, pemegang saham merupakan pihak eksternal perusahaan. Sehingga, para 
pemegang saham memiliki keterbatasan akses tentang segala informasi yang terdapat di dalam perusahaan.

Keputusan investasi yang baik salah satunya dipengaruhi oleh kualitas laporan keuangan yang baik pula. Ada beberapa penelitian terdahulu yang meneliti mengenai pengaruh kualitas laporan keuangan terhadap investasi. Verdi, (2006) menyatakan bahwa kualitas akrual berhubungan negatif dengan kondisi perusahaan berupa overinvestment dan underinvestment. Menurut (Biddle et al., 2009), kualitas laporan keuangan merupakan suatu ukuran ketepatan laporan keuangan dalam menyampaikan informasi mengenai kegiatan operasional perusahaan, terutama mengenai arus kas perusahaan kepada equity investor.

Equity investor merupakan pemegang saham dari perusahaan. Equity investor sebagai pemberi modal bagi perusahaan dan ingin memonitor segala kegiatan perusahaan agar modal yang ditanamkan di dalam perusahaan tidak menghilang begitu saja tanpa kejelasan. Menurut Priyakusuma (2013), Kualitas laporan keuangan yang diproksikan dengan Discretionary accrual memiliki pengaruh positif terhadap kondisi underinvestment. Sedangkan, kualitas laporan keuangan tidak berpengaruh terhadap kemungkinan perusahaan mengalami kondisi overinvestment.

Perusahaan yang menjadi subyek penelitian ini adalah perusahaan pertambangan yang terdaftar di Bursa Efek Indonesia. Perusahaan pertambangan merupakan salah satu penyumbang PDB yang sangat besar pengaruhnya bagi Indonesia. Perusahaan pertambangan merupakan salah satu sektor yang cenderung 
diminati oleh investor sebagai salah satu target investasinya. Penyebabnya adalah bahwa hasil dari pertambangan sangat digemari oleh masyarakat Indonesia.

Menurut data Badan Pusat Statistik bahwa industri pertambangan di Indonesia merupakan salah satu penyumbang PDB tertinggi. Sektor pertambangan di Indonesia mengalami peningkatan yang cukup tinggi pada tahun 2016 sedangkan pada tahun 2017 tetap mengalami peningkatan tetapi tidak signifikan seperti tahun sebelumnya. Hal ini diakibatkan karena menurunnya tren perdagangan Cina, karena Cina merupakan mitra dagang terbesar Indonesia. (www.cnnindonesia.com $)$. Hal ini akan mempengaruhi kegiatan investasi dalam sektor pertambangan. Dibuktikan oleh data yang ditunjukkan oleh BPS (Badan Pusat Statistik), terjadinya peningkatan PDB (Produk Domestik Bruto) sektor pertambangan di tahun 2017 yang tidak signifikan seperti pada tahun sebelumnya yaitu sebesar $4,2 \%$.

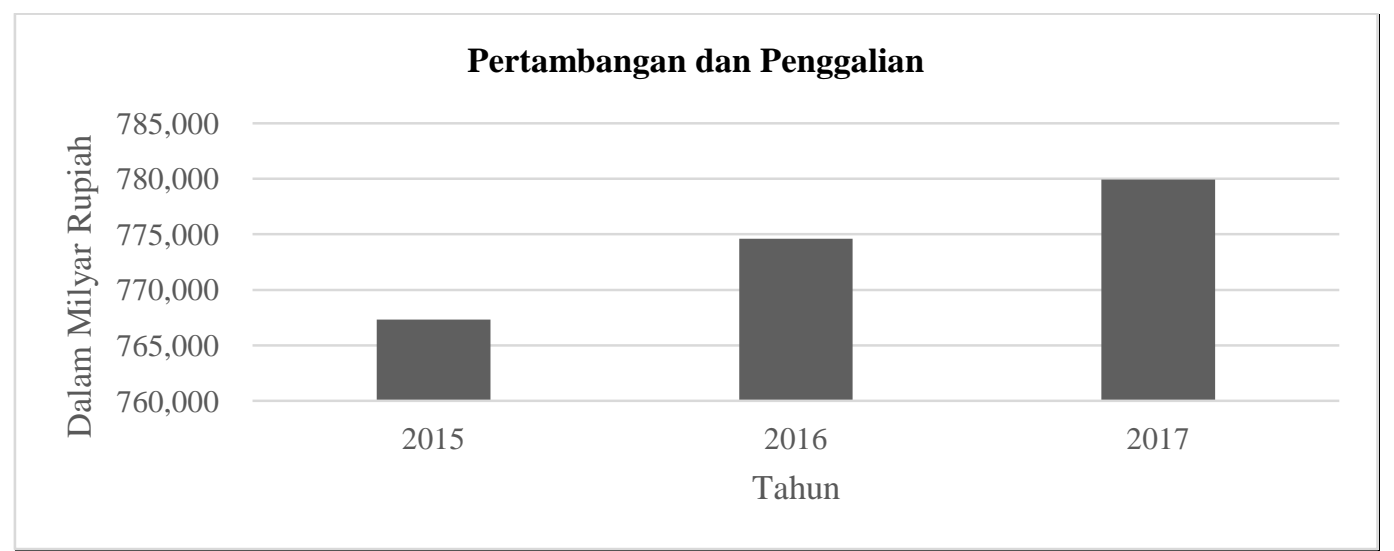

Gambar 1. Laju Pertumbuhan PDB Sektor Pertambangan Tahun 2015 Sumber: Data diolah, 2018

\section{7}

Berdasarkan uraian latar belakang masalah tersebut, maka yang menjadi rumusan masalah dalam penelitian ini adalah bagaimanakah pengaruh kualitas laporan keuangan pada kondisi underinvestment pada perusahaan pertambangan 
yang terdaftar di BEI pada tahun 2017? dan bagaimanakah pengaruh kualitas laporan keuangan pada kondisi overinvestment pada perusahaan pertambangan yang terdaftar di BEI pada tahun 2017?. Tujuan penelitian ini adalah untuk mengetahui pengaruh kualitas laporan keuangan pada kondisi underinvestment pada perusahaan tambanga yang terdaftar di BEI pada perusahaan pertambangan yang terdaftar di BEI tahun 2017 dan pengaruh kualitas laporan keuangan pada kondisi overinvestment pada perusahaan tambanga yang terdaftar di BEI pada perusahaan pertambangan yang terdaftar di BEI tahun 2017

Penelitian ini memberikan kontribusi tambahan pengetahuan terkait dengan pengaruh kualitas laporan keuangan terhadap efisiensi investasi. Penelitian ini dapat memberikan informasi bagi pihak manajer dalam membuat pertimbangan sehingga dapat mengambil langkah strategik menentukan investasi agar perusahaan terhindar dari kondisi underinvestment dan overinvestment.

Teori keagenan (agency theory) membahas tentang adanya hubungan keagenan antara prinsipal dan agen. Perspektif hubungan keagenan menjadi dasar yang digunakan untuk memahami keputusan investasi dari manajemen itu sendiri. Hubungan keagenan tercermin antara pihak manajemen (agen) dengan investor (prinsipal). Menurut Jensen \& Meckling (1976) teori keagenan adalah sebuah kontrak antara manajemen (agen) dengan pemilik (prinsipal). Agar hubungan kontraktual ini dapat berjalan lancar, pemilik akan mendelegasikan otoritas pembuatan keputusan kepada manajer. Perencanaan kontrak yang tepat bertujuan untuk menyelaraskan kepentingan manajer dan pemilik dalam hal konflik dan kepentingan, hal ini merupakan inti dari teori keagenan. 
Kaitan teori agensi dengan kualitas laporan keuangan dan efisiensi investasi adalah agen bertugas menjalankan perusahaan dan menghasilkan laporan keuangan sebagai bentuk dari pertanggungjawaban manajemen. Laporan keuangan ini nantinya akan menunjukkan kondisi keuangan perusahaan dan digunakan oleh prinsipal sebagai dasar pengambilan keputusan. Keputusan yang diambil oleh prinsipal adalah dalam hal menentukan investasi yang sekiranya dapat berguna bagi perusahaan.

Richardson (2006) mendefinisikan total investasi adalah segala pengeluaran perusahaan terkait dengan capital expenditures, akuisisi dan research and development dikurangi dengan hasil yang diperoleh dari penjualan property, plant and equipment. Dari pengertian tersebut dapat dikatakan bahwa jenis investasi perusahaan bisa berupa capital expenditures. Capital expenditures bisa berupa pembelian saham dan surat-surat berharga lainnya. Kemudian investasi bisa berupa pengeluaran untuk mengakuisisi perusahaan lain, namun bisa berupa pengeluaran terkait research and development dan pembelian atas aset tetap.

Investasi yang dilakukan perusahaan harus sesuai dengan kebutuhan dan sesuai dengan apa yang diharapkan perusahaan sehingga tercipta efisiensi investasi. Menurut Sari, (2014), efisiensi merupakan suatu tindakan untuk menggunakan sumber daya dengan tepat guna, tidak terjadi pemborosan sumber daya yang ada. Perusahaan melakukan efisiensi dengan tujuan menekan biaya dan untuk memudahkan proses pengelolaan perusahaan agar dapat mencapai tujuan perusahaan. Investasi yang dilakukan perusahaan haruslah efisien agar dapat mendatangkan manfaat bagi perusahaan. Efisiensi investasi merupakan tingkat 
investasi optimal dari perusahaan dimana investasi tersebut mendatangkan keuntungan yang bermanfaat bagi perusahaan (Sari, 2014).

Untuk mencapai investasi yang efisien, perusahaan seharusnya dapat terhindar dari kondisi overinvestment dan underinvestment. Kondisi overinvestment terjadi ketika perusahaan menghadapi kesempatan investasi yang mensyaratkan penggunaan hutang dengan jumlah yang besar tetapi tidak ada jaminan pembayaran hutang yang mencukupi (free cash flow). Perusahaan dengan tingkat leverage yang tinggi akan cenderung mengalami kondisi tersebut. Apabila ketika perusahaan tidak mampu merealisasikan investasi seperti yang diharapkan, perusahaan harus mencari alternatif tambahan dana. Dengan kata lain, overinvestment adalah kelebihan modal sedangkan underinvestment adalah kekurangan modal.

Investasi yang dilakukan perusahaan harus sesuai dengan kebutuhan dan sesuai dengan apa yang diharapkan perusahaan sehingga tercipta efisiensi investasi. Menurut Sari, (2014), efisiensi merupakan suatu tindakan untuk menggunakan sumber daya dengan tepat guna, tidak terjadi pemborosan sumber daya yang ada. Perusahaan melakukan efisiensi dengan tujuan menekan biaya dan untuk memudahkan proses pengelolaan perusahaan agar dapat mencapai tujuan perusahaan. Investasi yang dilakukan perusahaan haruslah efisien agar dapat mendatangkan manfaat bagi perusahaan. Efisiensi investasi merupakan tingkat investasi optimal dari perusahaan dimana investasi tersebut mendatangkan keuntungan yang bermanfaat bagi perusahaan (Sari, 2014). 
Untuk mencapai investasi yang efisien, perusahaan seharusnya dapat terhindar dari kondisi overinvestment dan underinvestment. Kondisi overinvestment terjadi ketika perusahaan menghadapi kesempatan investasi yang mensyaratkan penggunaan hutang dengan jumlah yang besar tetapi tidak ada jaminan pembayaran hutang yang mencukupi (free cash flow). Perusahaan dengan tingkat leverage yang tinggi akan cenderung mengalami kondisi tersebut. Apabila ketika perusahaan tidak mampu merealisasikan investasi seperti yang diharapkan, perusahaan harus mencari alternatif tambahan dana. Dengan kata lain, overinvestment adalah kelebihan modal sedangkan underinvestment adalah kekurangan modal.

Kualitas laporan keuangan adalah laporan keuangan yang di dalamnya memuat informasi yang tepat mengenai operasional perusahaan, khususnya arus kas yang diharapkan, yang menjadi sumber informasi bagi investor. Salah satu proksi yang banyak digunakan dalam mengukur kualitas laporan keuangan adalah pengukuran kualitas akrual dari Dechow \& Dichev (2002). Pengukuran ini muncul berdasarkan pemahaman bahwa akrual meningkatkan tingkat manfaat informasi dari laba dengan mengeluarkan fluktuasi arus kas yang sifatnya transitori. Pengukuran kualitas akrual Dechow \& Dichev (2002) ini sangat banyak digunakan dalam penelitian sebelumnya. Stubben (2010) mengusulkan sebuah model untuk mengukur kualitas akrual yang menggunakan salah satu komponen laba yang diduga bisa mengurangi kesalahan pengukuran.

Laporan keuangan dibuat dengan tujuan untuk digunakan oleh berbagai pihak, termasuk pihak internal perusahaan itu sendiri seperti manajer, karyawan, 
serikat buruh dan lainnya. Pihak-pihak yang sebenarnya paling berkepentingan dengan laporan keuangan adalah para pengguna eksternal (pemegang saham, kreditor, pemerintah, masyarakat). Para pengguna internal (para manajemen) mengetahui peristiwa-peristiwa yang terjadi pada perusahaan, sedangkan pihak eksternal yang tidak berada di perusahaan secara langsung, tidak mengetahui informasi tersebut sehingga tingkat ketergantungan manajemen terhadap informasi akuntansi tidak sebesar para pengguna eksternal. Salah satu kendala yang akan muncul antara agent dan principal adalah adanya asimetri informasi (information asymmetry).

Verdi (2006) menemukan bahwa laporan keuangan memiliki hubungan negatif terhadap over- atau underinvestment. Ia menyebutkan bahwa kualitas yang baik dari sebuah laporan keuangan dapat meningkatkan efisiensi investasi perusahaan dengan cara mengurangi asimetri informasi. Kemudian Biddle et al., (2009) menemukan bahwa kualitas laporan keuangan memiliki hubungan negatif dengan kondisi overinvestment dan underinvestment. Adanya kualitas pelaporan keuangan yang baik akan dapat meningkatkan fungsi monitoring dari pemegang saham sehingga dapat mengurangi kemungkinan terjadinya kondisi overinvestment atau underinvestment.

Cheng, Li, \& Wang, (2010) juga melakukan penelitian yang sama namun pada sampel perusahaan-perusahaan tertutup (private firms) di Amerika. Mereka menemukan bahwa kualitas laporan keuangan berhubungan negatif dengan kondisi over-popul dan underinvestment, walaupun pada perusahaan tertutup.Berdasarkan penjelasan di atas dan beberapa hasil penelitian yang telah 
dilakukan sebelumnya bahwa laporan keuangan memiliki pengaruh negatif terhadap over- atau underinvestment, maka dibentuklah hipotesis sebagai berikut:

$\mathrm{H}_{1} \quad$ : Kualitas laporan keuangan berpengaruh negatif terhadap kondisi underinvestment.

$\mathrm{H}_{2}$ : Kualitas laporan keuangan berpengaruh negatif terhadap kondisi overinvestment.

\section{METODE PENELITIAN}

Desain penelitian yang digunakan dalam penelitian ini adalah desain asosiatif. Pendekatan yang digunakan dalam penelitian ini adalah pendekatan kuantitatif dengan bentuk asosiatif. Desain dari penelitian terdapat dalam Gambar 2.

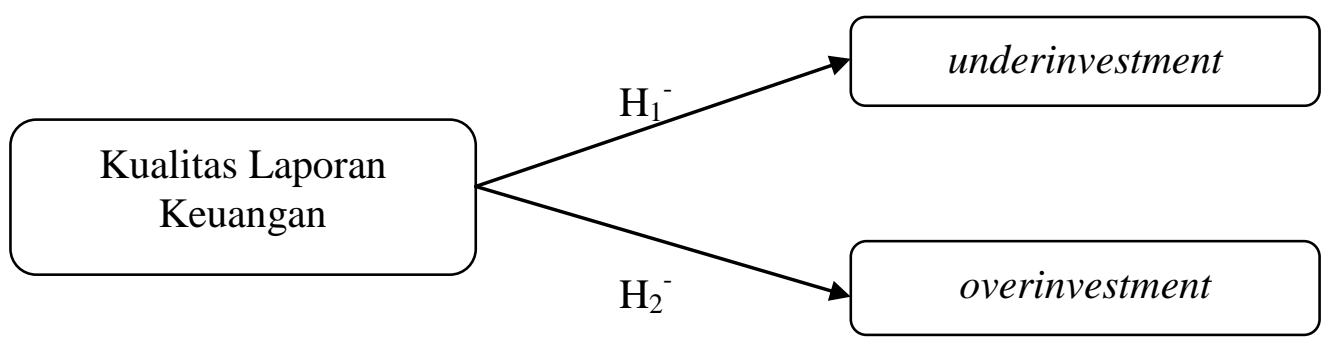

Sumber: Data diolah, 2018

Gambar 2. Desain Penelitian

Lokasi penelitian adalah tempat atau wilayah dimana penelitian tersebut dilakukan. Penelitian ini dilakukan di Bursa Efek Indonesia dengan mengakses website www.idx.co.id. dan mengunduh laporan tahunan perusahaan pertambangan tahun 2017.

Obyek penelitian adalah sasaran ilmiah untuk mendapatkan data dengan tujuan dan kegunaan tertentu tentang sesuatu secara objektif dan reliable (Sugiyono, 2017: 13). Objek penelitian ini adalah investasi pada perusahaan pertambangan yang terdaftar di Bursa Efek Indonesia. Investasi dijelaskan dengan 
kualitas laporan keuangan.Variabel terikat atau dependent variable adalah efisiensi investasi. Variabel bebas atau independent variable adalah kualitas laporan keuangan.

Untuk dapat mengukur efisiensi investasi perusahaan, maka digunakan model investasi dimana berfungsi sebagai growth opportunities. Model investasi yang digunakan mengikuti model investasi yang digunakan oleh Biddle et al. (2009). Menurut Biddle et al. (2009) total investasi/Investment didapat dari total investasi baru di mesin, peralatan, kendaraan, tanah dan gedung serta ditambah dengan biaya research and development dikurangi total penjualan aktiva tetap yang dibagi dengan total aktiva di tahun t. Berikut adalah model tersebut:

$$
\text { Investment }_{i, t+1}=\beta_{0}+\beta_{1} * \text { Sales Growth } \text { G }_{i, t}+\varepsilon_{i, t+1}
$$

Keterangan :

Investment $_{i, t+1}=$ ukuran dari total keseluruhan investasi yang dilakukan perusahaan i.

Sales Growth $_{i, t}=$ presentase dari perubahan penjualan dari tahunlalu hingga tahun ini.

Dengan menggunakan perhitungan model investasi (1) di atas, maka akan diperoleh nilai residual dari model tersebut. Besarnya nilai residual model tersebut nantinya akan digunakan sebagai proxy dari efisiensi investasi perusahaan. Mengikuti Biddle et al. (2009), nilai residual yang diperoleh dari masing-masing perusahaan akan diurut dari yang terbesar hingga terkecil. Kemudian nilai residual tersebut akan dibagi menjadi beberapa kuartil, dimana kuartil paling bawah merupakan perusahaan yang termasuk kategori underinvestment. Perusahaan pada kuartil paling atas akan dikategorikan sebagai perusahaan overinvestment. Sedangkan untuk kuartil tengah akan dijadikan sebagai kategori investasi normal. Kuartil paling atas diberi skor 3 atau 
dikategorikan sebagai overinvestment, kuartil tengah diberi skor 2 sebagai benchmark atau bisa dikatakan sebagai perusahaan dengan investasi normal, sedangkan kuartil paling bawah diberi skor 1 atau dikategorikan sebagai underinvestment.

Untuk bisa mengukur nilai dari akrual tersebut, maka penelitian ini akan mengikuti model pengukuran akrual yang terbaru yang dilakukan oleh (Kothari, Leone, \& Wasley (2005). Kothari et al. (2005)melakukan perbaikan dan modifikasi dari model perhitungan akrual yang sudah sering digunakan sebelumnya. Ia memperbaiki kekurangan dari model perhitungan akrual Jones \& modified Jones untuk memperoleh model baru yang hasil perhitungannya lebih akurat dan kuat dalam mengukur nilai akrual. Berikut adalah model perhitungan akrual yang dilakukan Kothari et al. (2005) :

$T A_{i, t}=\alpha_{0}+\alpha_{1} / \operatorname{ASSETS}_{i, t-1}+\alpha_{2} \Delta S A L E S_{i, t}+\alpha_{3} P P E_{i, t}+\alpha_{4} R O A_{i, t(o r i, t-1)}+\varepsilon_{i, t \ldots .}$

Keterangan :

$T A_{i, t} \quad=$ ukuran mengenai total akrual perusahaan i pada tahun $\mathrm{t}$

$\triangle S A L E S_{i, t} \quad=$ perubahan besarnya penjualan perusahaan i pada tahun $\mathrm{t}$

$P P E_{i, t} \quad=$ nilai bersih total aset tetap yang dimiliki perusahaan I pada tahun $\mathrm{t}$ $R O A_{i, t}$ or $_{i, t-1}=$ pengukuran kinerja yang berasal dari tingkatpengembalian aset. $\operatorname{ASSETS~}_{i, t-1} \quad=$ jumlah nilai total aset perusahaan pada periode sebelumnya

Mengikuti penelitian Kothari et al. (2005), total akrual diperoleh dari net income perusahaan dikurangi dengan nilai arus kas dari aktifitas operasi (cashflow from operation) perusahaan. $\triangle S A L E S_{i, t}$ dapat dihitung dengan menghitung selisih antara nilai penjualan tahun lalu dengan nilai penjualan tahun ini. $R O A_{i, t}$ diukur dengan cara net income dibagi dengan total aset perusahaan. Seluruh variabel tersebut akan dibagi dengan ASSETS $_{i, t-1}$. Kothari et al. (2005)membagi seluruh variabel dengan ASSETS $S_{i, t-1}$ bertujuan untuk mencegah terjadinya 
heterokedastisitas di dalam nilai residual yang diperoleh. Nilai residual yang diperoleh inilah yang akan digunakan sebagai ukuran dari kualitas laporan keuangan (Dechow \& Dichev, 2002). Nilai residual tersebut kemudian diabsolutkan, kemudian nilai absolut discretionary accrual ini akan digunakan sebagai pengukuran kualitas laporan keuangan.

Populasi dari penelitian ini adalah perusahaan pertambangan yang listing di Bursa Efek Indonesia (BEI) pada tahun 2017. Jumlah dari populasi perusahaan pertambangan yang listing di BEI pada tahun 2017 adalah 41 perusahaan. Pemilihan sampel penelitian didasarkan pada metode purposive sampling digunakan karena dalam penelitian ini ingin membahas tujuan atau topik tertentu dan kelebihan dari teknik purposive sampling ini relevan dengan tujuan penelitian. Sampel perusahaan yang digunakan dalam penelitian ini adalah 38 sampel.

Metode pengumpulan data yang digunakan yaitu metode observasi non partisipan dengan mengakses website Bursa Efek Indonesia (BEI) yaitu www.idx.co.id. Data kuantitatif dalam penelitian ini adalah laporan keuangan tahunan perusahaan pertambangan yang terdaftar di Bursa Efek Indonesia tahun 2017.

Analisis yang digunakan dalam penelitian ini adalah analisis regresi multinomial logistik dan uji statistika wald. Regresi logistik merupakan suatu pendekatan model matematis yang dapat digunakan untuk menyatakan hubungan beberapa variabel $\mathrm{X}$ terhadap variabel dependennya yang bersifat kategori. Regresi multinomial logistik digunakan untuk perluasan regresi logistik dengan 
variabel dependen yang lebih dari dua kategori. Variabel dependen dalam penelitian ini adalah efisiensi investasi yang dijelaskan menggunakan tiga kategori, yaitu:

1) Kategori $1:$ underinvestment

2) Kategori 2 : investasi normal (sebagai reference category)

3) Kategori 3 : overinvestment

Berikut adalah model regresi multinomial logistik dari penelitian ini.

$$
\begin{aligned}
& \operatorname{In}\left(\frac{P_{i 1}}{P_{i 2}}\right)=\beta_{01}+\beta_{11} X_{1} \\
& \operatorname{In}\left(\frac{P_{i 3}}{P_{i 2}}\right)=\beta_{03}+\beta_{13} X_{1}
\end{aligned}
$$

Keterangan:

$\mathrm{P}_{\mathrm{i} 1} \quad=$ probabilitas perusahaan i mengalami kondisi underinvestment

$\mathrm{P}_{\mathrm{i} 2}=$ probabilitas perusahaan i mengalami kondisi investasi normal

$\mathrm{P}_{\mathrm{i} 3}=$ probabilitas perusahaan i mengalami kondisi overinvestment

$\mathrm{X}_{1} \quad=$ kualitas laporan keuangan

Pengujian ini dilakukan untuk mengetahui apakah variabel independennya yaitu, kualitas laporan keuangan secara parsial berpengaruh terhadap variabel dependen yaitu, efisiensi investasi. Pengujian hipotesis dilakukan dengan cara membandingkan antara nilai probabilitas (sig) dengan tingkat signifikansi $(\alpha)$. Untuk menentukan penerimaan atau penolakan $\mathrm{H}_{0}$ berdasarkan pada tingkat signifikansi ( $\alpha$ ) 5\% dengan kriteria:

$\mathrm{H}_{0}$ tidak akan ditolak apabila statistic Wald hitung $<$ Chi-square tabel, dan nilai probabilitas $(\operatorname{sig})>$ tingkat signifikansi $(\alpha)$. Hal ini berrati $\mathrm{H}$ alternatif ditolak atau hipotesis yang menyatakan variabel bebas berpengaruh negatif terhadap variabel terikat ditolak. 
$\mathrm{H}_{0}$ ditolak apabila statistic Wald hitung > Chi-square tabel, dan nilai probabilitas $($ sig) $<$ tingkat signifikansi $(\alpha)$. Hal ini berarti $\mathrm{H}$ alternatif diterima atau hipotesis yang menyatakan variabel bebas berpengaruh negatif terhadap variabel terikat diterima.

\section{HASIL DAN PEMBAHASAN}

Proses seleksi berdasarkan kriteria yang telah ditetapkan, disajikan dalam Tabel 1.

Tabel 1.

Proses Pemilihan Sampel

\begin{tabular}{clc}
\hline No. & \multicolumn{1}{c}{ Keterangan } & Jumlah \\
\hline 1 & Perusahaan pertambangan yang terdaftar di BEI pada tahun 2017. & 41 \\
2 & Tidak menerbitkan laporan tahunan pada tahun 2017. & $(3)$ \\
& Total sampel yang terpilih sebagai sampel penelitian. & 38 \\
\hline
\end{tabular}

Sumber: Data diolah 2018

Berdasarkan data sekunder yang diperoleh dan diseleksi sesuai dengan kriteria yang sudah ditentukan, maka diperoleh sebanyak 38 sampel selama periode pengamatan tahun 2017.

Uji statistik deskriptif dilakukan untuk mendapatkan informasi menyeluruh mengenai data-data yang digunakan dalam penelitian. Informasi tersebut dapat berupa nilai maksimum, minimum, rata-rata (mean), dan standar deviasi dari data-data penelitian. Hasil uji statistik deskriptif dapat dilihat pada Tabel 2 berikut. 
Tabel 2.

Statistik Deskriptif

\begin{tabular}{lrrrrr}
\hline & $\mathrm{N}$ & Minimum & Maximum & Mean & Std. Deviation \\
\hline Kualitas Laporan Keuangan & 38 & $-0,773$ & 1,466 & 0,480 & 0,410 \\
Efisiensi Investasi & 38 & 1,000 & 3,000 & 2,000 & 0,735 \\
Valid $\mathrm{N}$ (listwise) & 38 & & & & \\
\hline
\end{tabular}

Sumber: Data diolah, 2018

Berdasarkan Tabel 2 dapat diketahui bahwa total sampel yang digunakan adalah sebanyak 38 perusahaan. Nilai kualitas laporan keuangan paling rendah (minimum) adalah sebesar -0,773 persen dimiliki oleh CKRA dan kualitas laporan keuangan yang paling tinggi (maksimum) adalah sebesar 1,466 persen yang dimiliki oleh BSSR. Kualitas laporan keuangan memiliki nilai rata-rata sebesar 0,480 persen, dengan nilai standar deviasi sebesar 0,410 persen. Hal ini berarti nilai ini lebih rendah dibandingkan dengan nilai rata-rata, yang artinya sebaran data terkait kualitas laporan keuangan sudah merata.

Nilai efisiensi investasi paling rendah (minimum) adalah sebesar 1 yang berarti underinvestment dan efisiensi investasi yang paling tinggi (maksimum) adalah sebesar 3 yang berarti overinvestment. Efisiensi investasi memiliki nilai rata-rata sebesar 2 , dengan nilai standar deviasi sebesar 0,735 . Hal ini berarti nilai ini lebih rendah dibandingkan dengan nilai rata-rata, yang artinya sebaran data terkait efisiensi investasi sudah merata.

Tabel Model Fitting Information digunakan untuk meneliti perubahan pada model apabila seluruh variabel dimasukkan dibandingkan bila hanya intersep yang dimasukkan kedalam model. Hasil uji Model Fitting Information dapat dilihat pada Tabel 3 berikut. 
Tabel 3.

Model Fitting Information

\begin{tabular}{lrrrr}
\hline Model & Model Fitting & & \\
& Criteria & & & \\
& -2 Log & & & \\
& Likelihood & Chi-Square & $\mathrm{df}$ & Sig. \\
\hline Intercept Only & 143,248 & & & \\
Final & 62,948 & 80,300 & 74 & 0,028 \\
\hline Sumber : Data diolah, 2018 & & &
\end{tabular}

Tabel 3 menunjukkan nilai -2 log likelihood semakin kecil atau mengalami penurunan dari 143,248 hingga 62,948, maka model tersebut menunjukkan model regresi yang baik.

Regresi logistik merupakan suatu pendekatan model matematis yang dapat digunakan untuk menyatakan hubungan beberapa variabel $\mathrm{X}$ terhadap variabel dependennya yang bersifat kategori. Regresi multinomial logistik digunakan untuk perluasan regresi logistik dengan variabel dependen yang lebih dari dua kategori. Hasil menunjukkan bahwa nilai signifikansi kurang 0,05, sehingga dapat disimpulkan bahwa ada pengaruh yang signifikan antar variabel penelitian.

Pengujian statistika Wald dilakukan untuk mengetahui apakah variabel independennya yaitu, kualitas laporan keuangan secara parsial berpengaruh terhadap variabel dependen yaitu, efisiensi investasi. Hasil uji statistik wald dapat dilihat pada Tabel 4 berikut. 
Tabel 4.

Rangkuman Hasil Uji Wald

\begin{tabular}{|c|c|c|c|c|c|c|c|}
\hline \multirow[t]{6}{*}{ Efisiensi Investasi $^{\mathrm{a}}$} & \multirow[b]{6}{*}{ B } & \multirow[b]{5}{*}{$S t d$} & \multirow[b]{6}{*}{ Wald } & \multirow[b]{6}{*}{ df } & \multirow[b]{6}{*}{ Sig. } & \multirow[b]{6}{*}{$\operatorname{Exp}(B)$} & $95 \%$ \\
\hline & & & & & & & Confidence \\
\hline & & & & & & & Interval for \\
\hline & & & & & & & $\operatorname{Exp}(B)$ \\
\hline & & & & & & & Lower Upper \\
\hline & & Error & & & & & Bound Bound \\
\hline underinvestment Intercept & $-18,897$ & 4011,785 & 0,996 & 1 & 0,000 & & \\
\hline overinvestment & $-18,309$ & 9455,869 & 0,998 & 1 & 0000 & & \\
\hline
\end{tabular}
Sumber : Data diolah, 2018

Hasil uji pada Tabel 4 menunjukkan nilai statistic Wald hitung sebesar 18,897 > Chi-square tabel $(3,841)$, dan nilai probabilitas (signifikansi sebesar $0,000)<$ tingkat signifikansi $(\alpha=0,05)$. Hal ini berarti Hipotesis alternatif diterima atau hipotesis yang menyatakan variabel kualitas laporan keuangan berpengaruh negatif terhadap variabel efisiensi investasi diterima.

Berdasarkan tabel uji statistika Wald, menunjukkan bahwa kualitas laporan keuangan berpengaruh negatif terhadap kondisi underinvestment sehingga hipotesis pertama dalam penelitian ini diterima. Perusahaan dengan nilai kualitas laporan keuangan yang tinggi akan menyebabkan menurunnya probabilitas perusahaan yang mengalami kondisi underinvestment dibandingkan dengan probabilitas perusahaan dalam kondisi investasi normal. Kualitas informasi akuntansi yang baik akan dapat membantu mengurangi adanya asimetri informasi antara pemegang saham sebagai principal dan manajer sebagai agent. Kualitas laporan keuangan yang tinggi akan dapat mencegah perusahaan mengalami kondisi underinvestment. Perusahaan dikatakan underinvestment jika perusahaan banyak melewatkan proyek-proyek investasi yang memiliki nilai NPV tinggi. Dengan sumber daya yang dimiliki perusahaan dan investment opportunities yang 
dihadapi perusahaan, perusahaan seharusnya mampu untuk mengambil proyekproyek investasi dengan nilai NPV tinggi tersebut. Informasi yang diterima antara manajer dan pemegang saham tentang kondisi perusahaan berbeda. Pemegang saham menginginkan kesejahteraan mereka meningkat, sedangkan manajer menginginkan kesejahteraan dirinya meningkat. Manajer akan melakukan berbagai cara untuk bisa menigkatkan kesejahteraan dirinya, walaupun harus melewatkan proyek investasi yang layak. Hal tersebut dapat dicegah dengan kualitas laporan keuangan yang baik (Beatty, A., Liao, S., \& Weber, 2009). Kualitas laporan keuangan yang baik dapat berfungsi sebagai alat monitoring atas keputusan investasi yang dibuat oleh manajer (Bens, D.A., \& Monahan, 2002). engan begitu total investasi perusahaan tidak lagi lebih rendah dari total investasi yang diprediksikan (predicted level of investment). Sehingga perusahaan bisa terhindar dari kondisi underinvestment dan kegiatan investasi dari perusahaan tersebut akan menjadi lebih efisien. Penelitian Biddle et al. (2009) menemukan bahwa kualitas laporan keuangan memiliki hubungan negatif dengan kondisi underinvestment. Adanya kualitas pelaporan keuangan yang baik akan dapat meningkatkan fungsi monitoring dari pemegang saham sehingga dapat mengurangi kemungkinan terjadinya kondisi underinvestment. Cheng et al. (2010) juga melakukan penelitian yang sama namun pada sampel perusahaanperusahaan tertutup (private firms) di Amerika, dengan hasil bahwa kualitas laporan keuangan berhubungan negatif dengan kondisi underinvestment, walaupun pada perusahaan tertutup. Verdi (2006) menemukan bahwa laporan keuangan juga memiliki hubungan negatif terhadap kondisi underinvestment. 
Disebutkan bahwa kualitas yang baik dari sebuah laporan keuangan dapat meningkatkan efisiensi investasi perusahaan dengan cara mengurangi asimetri informasi.

Hasil uji statistika Wald sebelumnya menunjukkan bahwa kualitas laporan keuangan berpengaruh negatif terhadap kondisi overinvestment sehingga hipotesis kedua $\left(\mathrm{H}_{2}\right)$ dalam penelitian ini diterima. Dapat dikatakan bahwa kualitas dari laporan keuangan dapat mempengaruhi kondisi investasi perusahaan berupa overinvestment. Ditemukan bahwa kualitas laporan yang baik berhubungan dengan probabilita perusahaan mengalami kondisi overinvestment di perusahaan sektor pertambangan terdaftar BEI pada tahun 2017. Dalam penelitian ini, ternyata kualitas laporan keuangan yang baik dapat meningkatkan fungsi monitoring bagi pemegang saham dalam mengawasi keputusan investasi yang dibuat oleh manajer. Hal tersebut disebabkan oleh kondisi investasi di sektor pertambangan pada tahun 2017 yang meningkat dari tahun sebelumnya. Ini disebabkan karena adanya perang dagang antara Cina dan Amerika yang telah dijelaskan dalam latar belakang penelitian ini.

Dengan kondisi tersebut, kemungkinan investor tertarik untuk berinvestasi di sektor pertambangan pada tahun 2017. Suntikan dana yang didapat oleh perusahaan akan berdampak pada kondisi investasinya. Perusahaan kemungkinan akan mengalami kondisi overinvestment karena dengan kondisi tersebut, perusahaan kemungkinan akan cenderung menggunakan dana tersebut untuk berinvestasi. Manajer akan lebih memilih menggunakan dana arus kas bebas (free cash flow) untuk dibagikan kepada pemegang saham dalam bentuk deviden 
daripada menggunakan dananya untuk berinvestasi di proyek-proyek yang kurang menguntungkan. Ini bertujuan agar pemegang saham tetap ingin berinvestasi pada perusahaan tersebut.

Hasil penelitian ini tidak sesuai dengan apa yang ditemukan Priyakusuma (2013), dan Dwiwana (2012). Namun hasil ini sejalan dengan penelitian yang telah ditemukan sebelumnya oleh Verdi (2006), Biddle et al. (2009) dan Cheng et al. (2010). Menurut Verdi (2006), kualitas laporan keuangan berpengaruh negatif terhadap overinvestment karena dalam penelitiannya menggunakan kualitas akrual sebagai salah satu proksi dalam kualitas laporan keuangan. Kualitas akrual sebagai proksi dari kualitas laporan keuangan memiliki peranan yang sangat penting dalam hal mengurangi asimetri informasi dalam suatau perusahaan (Biddle et al., 2009).

\section{SIMPULAN}

Kualitas laporan keuangan berpengaruh negatif terhadap kondisi underinvestment. Hasil ini menunjukkan bahwa perusahaan dengan nilai kualitas laporan keuangan yang tinggi akan menyebabkan menurunnya probabilitas perusahaan yang mengalami kondisi underinvestment dibandingkan dengan probabilitas perusahaan dalam kondisi investasi normal. Kualitas informasi akuntansi yang baik akan dapat membantu mengurangi adanya asimetri informasi antara pemegang saham sebagai principal dan manajer sebagai agent.

Kualitas laporan keuangan berpengaruh negatif terhadap kondisi overinvestment. Dapat dikatakan bahwa kualitas dari laporan keuangan dapat 
mempengaruhi kondisi investasi perusahaan berupa overinvestment. Ditemukan bahwa kualitas laporan yang baik berhubungan dengan probabilita perusahaan mengalami kondisi overinvestment. Kualitas laporan keuangan yang baik dapat meningkatkan fungsi monitoring bagi pemegang saham dalam mengawasi keputusan investasi yang dibuat oleh manajer.

Saran dari penelitian bagi perusahaan adalah agar mampu memutuskan kebijakan investasi bagi perusahaan agar terhindar dari kondisi underinvestment dan overinvestment. Bagi peneliti selanjutnya, dapat menggunakan variabel lain dan memperluas sampel penelitian. Memasukkan variabel tambahan maturitas utang, jatuh tempo utang, risiko litigasi, karakteristik perusahaan, tata kelola perusahaan, dan struktur kepemilikan.

\section{REFERENSI}

Beatty, A., Liao, S., and Weber, J. (2009). Financial Reporting Quality, Private Information, Monitoring and The Lease-Versus-Buy Decision. Working Paper Ohio State University.

Bens, D.A., and Monahan, S. . (2002). Disclosure Quality and The Excess Value of Diversification. Journal of Accounting Research, 42, 691-730.

Biddle, G. C., Hilary, G., \& Verdi, R. S. (2009). How Does Financial Reporting Quality Relate to Investment Efficiency? Journal of Accounting and Economics, 48(2-3), 112-131. https://doi.org/10.1016/j.jacceco.2009.09.001

Cheng, F., Li, Q., \& Wang, X. (2010). Financial Reporting Quality and Investment Efficiency of Private Firms in Emerging Markets. The Accounting Review, 86, 1255-1288.

Dechow, P., \& Dichev, I. (2002). The Quality of Accruals and Earnings: The Role of ACcrual Estimation Errors. The Accounting Review, 77, 35-39.

Dwiwana, B. (2012). Pengaruh Kualitas Laporan Keuangan dan Tata Kelola Terhadap Efisiensi Investasi. 
Jensen, M. (1986). Agency Costs of Free Cash Flow, Corporate Finance, and Takeovers. American Economic Review, 76, 323-329.

Jensen, M. C., \& Meckling, W. H. (1976). Theory of The Firm: Managerial Behaviour, Agency Cost and Ownership Structure. Journal of Financial Economics, 3(4), 305-360.

Kothari, S. P., Leone, A. J., \& Wasley, C. E. (2005). Performance Matched Discretionary Accrual Measures William E . Simon Graduate School of Performance Matched Discretionary Accrual Measures. Journal of Accounting and Economics, 39, 163-197.

Priyakusuma, I. (2013). Pengaruh Kualitas Laporan Keuangan Terhadap Efisiensi Investasi Perusahaan. Skripsi: Fakultas Ekonomi Universitas Indonesia.

Richardson, S. (2006). Overinvestment of Free Cash Flow. Review of Accounting Studies, 11, 159-189.

Ross, S. A., Westerfield, R., \& Jordan, B. D. (2008). Fundamentals of Corporate Finance (8th Edition). New York; McGraw-Hill.

Sari, L. I. N. dan I. G. N. A. S. (2014). Pengaruh Kualitas Laporan Keuangan Pada Efisiensi Investasi Perusahaan Pertambangan. E- Journal Akuntansi Universitas Udayana, 8(3), 524-537.

Stubben, S. R. (2010). Discretionary Revenues as Measure of Earnings Management. The Accounting Review, 85(2), 695-717.

Verdi, R. S. (2006). Financial Reporting Quality and Investment Efiiciency. Sloan School of Management Massachusetts Institute of Technology. 